\title{
DEPARTMENT OF THE INTERIOR.
}

UNITED STATRS GWOLOGICAL AND GEOGRAPHICAL SURVEY OP THIE TERRITORIRS. F. V. HAYDEN, U. S. Geologist-in-Charge.

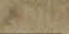

I.-DESCRIPTIONS AND ILLUSTRATIONS OF FOSSILS FROM VANCOUVER'S AND SUCIA ISLANDS, AND OTHER NORTHWESTERN LOCALITIES.

By F. B. MEEK.

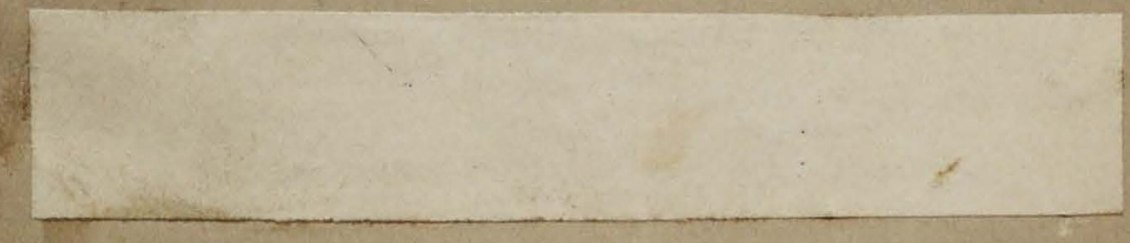

EXTRACTED FROM BULLETIN OF THE GEOLOGICAL AND GEOGRAPHICAL SURVEY OF THE TERRITORIES, VOL. II, NO. 4. 
W. E. CRANE

LIBRARY 


\section{DESCRIPTIONS AND ILLUSTRATIONS OF FOSSILS FROM VAN- COUVER'S AND SUCIA ISLANDS, AND OTHER NORT'HWESTERN LOCALITIES.}

By F. B. Meek, Palcontologist.

The fossils described and illustrated in this paper were in part collected by Mr. George Gibbs, geologist of the Northwestern Boundary Survey, under the direction of Archibald Campbell, esq., the commis. sioner appointed in behalf of the United States Government on the joint commission for the survey of the Northwestern Boundary-line.

Most of the Cretaceous species from Vancouver's Island, however, had been some time previously sent on to the Smithsonian Institution, and briefly described, without illustrations, in a paper published by the writer in the Transactions of the Albany Institute (vol. iv, 1856), for the first time announcing the discovery of Cretaceous rocks at that distant northwestern locality. On the return of the Boundary commission in 1861, the additional collections of fossils obtained during that survey were submitted to the writer for study, and preliminary descriptions of those believed to be new were published in the Proceedings of the Phil. adelphia Academy of Natural Sciences for that year. Soon after, the following more extended descriptions, and the accompanying plates of drawings of these fossils, were prepared for publication in Mr. Campbell's report, in connection with that of Mr. Gibbs, on the geology of the country along the line of the boundary. None of the elaborate geolog. ical or natural history results, however, of this survey were published in Mr. Campbell's report; and consequently none of the descriptions and drawings, as presented in this paper, were ever issued. In the mean time, figures of four or five of the Cretaceous species have been published (mainly without descriptions) in the reports of the geological survey of California; but the other species have not hitherto been illustrated, nor any of them described with much detail.

As it has, therefore, been considered very desirable that full descriptions of all of these species, with figures of the same, from the original typical specimens, should be published, permission was obtained through Mr. Gibbs, the geologist of the survey, to publish this paper through whatever agency might be found most convenient.

All of the fossils under consideration, with possibly the exception of one Tertiary species, it will be seen, belong to the Carboniferons and Cretaceous systems. Those of Carboniferous age come from the eastern slope of the second principal range of the Rocky Mountains, near a small stream known as Katlahwoke Creek, latitude $49^{\circ}$ north, and longitude $114^{\circ}$ west from Greenwich; this being the highest northern point, it is believed, at which rocks of this age have yet been identified by organic remains along the Rocky Mountain range. They are contained in a hard gray and bluish-gray limestone, breaking with a rough, irregular fracture, and sometimes presenting an obscurely subcrystalline structure. These limestones, according to the observations of Mr. Gibbs, 
erop out along the slope of the mountain, while reddish and yellowish ripple-marked sandstones compose the upper part of the same. Below the limestone, he saw exposures of a whitish fine sandstone, hand specimens of which closely resemble examples of the Potsdam sandstone brought by Dr. Hayden from the Black Hills and several localities along the Rocky Mountains, where that rock is known to be immediately overlaid by Carboniferous limestones.

Fossils are apparently rare in this Carboniferous limestone, near the line of the boundary survey, where they are usually so firmly imbedded in the hard brittle matrix that no specimens were procured in a condition to show very elearly their specific characters. Those collected con. sist of a small Zaphrentis, a" Spirifer allied to S. Keokuk, a small Athyris apparently undistinguishable from $A$. subtilita, and a large Productus agreeing nearly with $P$. latissimus, Sowerby.

From these fossils, we can safely refer this rock to the Carboniferous system, and even with some degree of confidence, to the lower or Mount. ain Limestone series of the same. It is true, Athyris subtilita is generally, in this country, regarded as a Coal-Measure species; but we have a form in the Lower Carboniferous series of the Mississippi Valley. scarcely distinguishable, wheh is even by some regarded as a variety of A. subtilita; while Mr. Davidson identifies that species in the Lower Carboniferous rocks of England. Spirifer Keokuk and Productus latissimus are both Lower Carboniferous species, while the latter is very unlike any of our known American Coal-Measure species. In its lithological characters, the matrix containing these fossils likewise agrees well with beds in the region of the Great Salt Lake containing Lower Carboniferous fossils, and apparently the same Spirifer mentioned above; while it is quite unlike any of the known beds of the Far. West that can be certainly referred to the Coal-Measures.

The presence here of Carboniferous rocks would seem to lend at least. some encouragement to the hope that true coal of Carboniferous age may be found at some place along the Rocky Mountains farther south, near the line of the North Pacific Railroad.

A few fragments of apparently Carboniferous or possibly Devonian fossils were also found on a small tributary of Fraser River, about fifty miles from the Gulf of Georgia. They occur in a dark, very hard, partly metamorphosed limestone, and consist of crinoid columns, and a portion of a large Zaphrentis. The crinoid columns have been dissolved out, and the cavities subsequently filled with calcareous matter retaining the original form, but not the structure of the fossils. Some of the columns measure as much as 0.80 inch in diameter, and show by the constrictions in the comparatively large central cavity some fourteen or fifteen segments in the space of an inch. The Zaphrentis, when entire, must have measured about $2 \frac{1}{2}$ inches in diameter at the larger end, being nearly as large as the Deronian $Z$. gigantea, though proportionally shorter, more abruptly tapering, and apparently more curved. None of these specimens, however, were in a condition to be figured.

The Cretaceous fossils contained in the collection are from two localities on Vancourer's Island, and in part from Sucia Islands in the Gulf of Georgia. Those originally sent to the Smithsonian Institution were all from Vancouver's Island, and at the time they were examined by the writer, were supposed to have been all obtained from one locality, though we now know that they came from two distinct localities. They gave evidence, in the nature of the matrix, however, as well as in the speeies, of having been obtained from two different beds or rocks, one of which was unhesitatingly referred to the Cretaceous epoch. The specimens 
from the other bed at Nanaimo being, so far as determined, all new species, and belonging apparently to genera common to the Cretaceous and Jurassic systems, some doubts were entertained whether or not they might belong to the latter; though it was stated that from their general characters and affinities, it appeared more probable that they belonged also to the Cretaceous. On looking them over some time after, however, the writer was led to suspect that they might be of Jurassic age, which suggestion was mentioned to Dr. Newberry, who referred to it in his report on the geology of Captain Williamson's Pacific Railroad Survey.

A review of the whole subject, however, with the aid of the additional light derived from the more extensive collections brought in by the Northwestern Boundary Survey, fully confirmed the original conclusion that the whole belong to the Cretaceous. One of the strongest evidences of this is the occurrence, in these beds at Nanaimo, of numerous dico- tyledonous leares, of so modern an aspect that some who have examined these leaves alone, without regard to the associated molluscan remains, have even thought that these beds ought to be referred to the Tertiary.* That they do not belong to the Tertiary, however, is evident from the fact that they also contain a large species of Inoceramus and a Goniomya, together with Cretaceous types of Trigonia and Pholadomya.

The Nanaimo locality is on the eastern shore of Vancouver's Island, and Komooks, or Komax, $\dagger$ which is also on the eastern shore of the same, is about sixty to seventy miles farther northwest; while the Sucia Islands are in the Gulf of Georgia, about the same distance in a southeast direction from Nanaimo. At the Nanaimo locality, the beds consist of sandstone, good coal, and conglomerates, composed of small pebbles, with seams of greenish-gray and brownish beds of arenaceous matter containing fossils, the whole dipping eastward. The same beds also occur on the neighboring Douglass and New Castle Islands, where they likewise contain coal. These beds seem to be quite distinct from those at Komooks and on Sucia Islands, both in their fossils and in their lithological characters; and from the affinities of their fossils, as as well as from the direction of the dip of the strata, I am inclined to believe them older than those seen on the Suica Islands and at Komooks, though the whole seems to belong to division A of the California reports. The Nanaimo beds do not seem to be equivalent to any of the subdivisions recognized in the Upper Missouri country.

The Komooks and Sucia Island beds, however, appear, both from the affinities of their fossils, and from the state of preservation of the latter, to be related to what we have called the "Fort Pierre group", or division No. 4 of the Upper Missouri section. In the latter district, this division is composed mainly of dark plastic and indurated clays, in which the fossils often occur enveloped in hard concretions, and show the substance of the shells in a beautiful state of preservation. Those from Komooks and Sucia Islands are in a similar state of preservation, and appear to have been enveloped in similar concretions; while the specimens from Nanaimo are mainly casts, or, where they retain any portion of the shell, it is more decomposed and has an older look. Among the species from Komooks and Sucia Islands, some of the Bacu. lites and a Nautilus are related to species found in No. 4 of the Upper Missouri, while one of the Ammonites and one of Inoceramus appear scarcely to differ more than as varieties from forms found in the horizon mentioned in the Upper Missouri.

\footnotetext{
* These plant-remains have been investigated by Dr. Newberry, and by him referred to the Cretaceous.

† Mr. Gabb writes this name "Komax" in the California report.
} 
These Sucia and Komooks beds are also almost certainly representatives of those of the New Jersey Greensand series, containing Ammonites complexus, Placenticeras placenta, Nautilus Dekayi, Baculites ovatus, Gryphaca vesicularis, Inoceramus Barabini, \&c., as well as of the Upper Chalk of Europe.

Smithsonian Institution, Washington City, June, 1871.

\title{
CARBONIFEROUS SHECIES.
}

\section{BRACHIOPODA.}

\section{Genus PRODUCTUS, Sowerby.}

\author{
Productus iatiss:mus, Sowerby.
}

\author{
Pli te 1, fig. 1 .
}

Productus latissimus, Sowerby (1822), Mineral Conch., pl. 330.-Phillips (1836), Geol. Yorks., ii, pl. viii, fig. 1.-DeKoninck (1847), Monogr Chonetes et Prod., pI. ii, fig. 2; and pl. iii, fig. 2.-Davidson (1861), Scottish Carb. Brach., pl. ii, figs. 8,9 ; and (1857), Monogr. British Carb. Brach., 145, pl. xxv, figs. 1-4.

Shell attaining a large size, thin, rather depressed, much wider than long, with a subsemicireular outline; anterior margin not produced; hinge-line long, straight, but apparently not quite equaling the greatest breadth. Ventral valve moderately convex or arched, with a regularlyincreasing curve from the front to the beak; anterior margin not produced and presenting a more or less nearly semicircular outline; beak incurved, but not prominent; lateral extremities slightly rounded; ears more or less arched, and not in any way defined from the convexity of the central region, which is nearly or quite without a mesial sinus; sears of divaricator muscles distinct and subquadrate; surface without concentrie wrinkles, and marked by moderately distinct, rounded, rather small, radiating costæ, or coarse striæ, that generally increase by intercalation, and number about four or five in the space of $0.20 \mathrm{inch}$, near the front. Dorsal valve unknown.

Length, 1.67 inches; breadth, about 2.53 inches; convexity, 0.71 inch.

Although I have seen only very imperfectly-preserved specimens of this shell, they agree so nearly in almost all of their known characters with $P$. latissimus of Sowerby that I can scarcely doubt their identity with that species, which has not, I believe, before been even provisionally identified from any American locality. None of our specimens show the little short spines seen on the ventral valve of Sowerby's species, but they are all more or less worn, while some slight remains of what appear to be the bases of a few of these spines are seen on some of the specimens.

At first I was rather inclined to think this shell might belong to the closely-allied $P$. giganteus of Martin; but the fact that well-preserved internal casts of the rentral valve show no traces of the cavities for the reception of the internal spiral arms, such as occur in $P$. giganteus, favors the conclusion that it more probably belongs to $P$. latissimus. It also agrees with the latter, and differs from the former, in having its ears passing gradually into the convex part of the shell without any depressions to mark the limits between these parts. This latter character, and the lateral extension of the ears, however, are better seen in 
some specimens in the collection too imperfect to be figured, than in the one from which the figure given on plate 1 was drawn.

Locality and position.-Carboniferous limestone, at Katlahwoke Creek, just west of the principal range of the Rocky Mountains, latitude $49^{\circ}$ north, longitude $114^{\circ}$ west.

\section{Genus SPIRIFER, Sowerby.}

\section{Spirifer KeOKUK, Hall?}

Plate 1, figs. 3, 3, a.

Spirifer Keokuk, Hall (1858), Geol. Report Iowa, i, 642, pl. xx, figs. 3, a-d, and $2 d$. Spirifer Keokuk, var., ib., 676, pl. xxiv, figs. 4, a,b,c,d.

The specimens of this Spirifer in the collection are very imperfect; but as far as their characters ean be made out, they present no peculiarities by which they can be distinguished from the shell described by Professor Hall under the name S. Keokuk. Colonel Simpson, Mr. King, and Dr. Hayden have also brought, from dark-bluish and gray limestones at various localities in Utah and other far western districts, specimens of apparently the same shell. There is also in the CoalMeasures of the Western States a Spirifer that has been described by Professor Hall under the name S. opimus, in his Iowa Report (and, as I think, more recently by Professor McChesney, under the name $S$. subventricosus), that seems to be rery closely allied.

Locality and position.-Gray Carboniferous limestove; Kootenay range of Rocky Mountains.

\section{Genus ATHYRIS, McCoy, 1844,=SPIRIGERA, d'Orbigny, 1847.}

Athyris subtilita, Hall (sp.).

Plate 1, figs. 2, 2 a.

Terebratula Roysii, d'Orbigny (18ł2), Voy. dans l'Amér. Mórid., viii, 44, pl. iii, figs. 17-19; (not L'Eveillé (sp.), 1835).

Terebratula exbtilita, Hall (1852), in Stansbury's Report Exp. to Great Salt Lake, 409 , pl. iv (by error pl. ii), figs. 1, $a, b$, and 2, $a, b$.-Schiel (1855), Report Pacific R. R. Survey, ii, 108, pl. 1, figs. 2, a, b.-Davidson? (1856), Brit. Carb. Brach., 18, pl. 1, figs. 21 and 22.-Hall (1856), Report Pacific R. R., iii, 101, pl. ii, figs. 1 and 2.-Marcou (1858), Geol. N. Am., 52, pl. vi, fig. 9, $a, b, c, d, e, f$.

Athyris subtila, Davidson (1856), British Carb. Brach., 86 , pl. i, tigs. 21 and 22 , and pl. xvii, figs. 8-10.-Salter (1861), Qr. Jour. Geol. Soc. Lond., 64, pl. iv, fig. 4.

As nearly as can be determined from a single specimen of the shell under consideration, it appears to agree well with $A$. subtilita in form and general appearance. It is smaller, howerer, than the usual adult size of that species; but, like other species of the genus, that shell is known to vary considerably in size at different localities.

In the Mississippi Valley, A. subtilita is usually regarded as being confined to the Coal-Measures and Permo-Uarboniferous beds; but the British examples cited above came from the Lower Carboniferous. We have in our Lower Carboniferous (Chester group) a form described, by

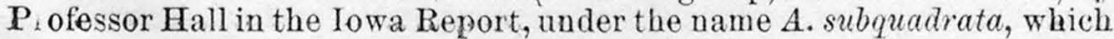


so nearly resembles it that sone consider the latter as only a variety of A. subtilita.

Locality and position.-Katlahwoke Creek, just west of the second principal range of the Rocky Mountains; latitude $49^{\circ}$ north, longitude 1140 west; Carboniferous.

\title{
CRETACEOUS SPECIES. \\ LAMELLIBRANCHIATA.
}

\author{
Genus NUCULA, Lamarck.
}

Nucula Traskana, Meek.

Nucula Traskana Meek (185i), Trans. Albany Inst., iv, 39.

Shell trigonal-ovate, with both extremities rather narrowly rounded; cardinal border sloping from the beaks at an angle of about one hundred degrees; base forming a broad gentle curve; beaks nearly central, rather elevated; surface unknown; muscular impressions shallow; hinge having in each valve about fifteen teeth on each side of the small pit for the reception of the ligament.

Length, 0.27 inch; height, 0.18 inch; breadth, 0.16 inch.

The only specimen of this species that I have seen is a cast, which is so much worn as to show imperfectly the surface characters. As nearly as can be determined, it appears to have been provided with rather distinct concentric lines of growth; and, judging from a depression along the anterior slope of the cardinal margin, it was probably provided with a well-defined lunule. The species will probably be recognized by its ventricose trigonal-ovate form, and nearly ceutral beaks.

Since first describing this species, the only specimen in the collection has been mislaid, so that I am unable to give a figure of it. The speeific name was given in honor of Dr. John B. Trask, of San Francisco.

Locality and position.-The specimen came with others labeled "Nanaimo, Vanconver's Island"; though it may have been collected at Komooks.

\section{Genus GRAMMATODON, Meek.}

\section{Gramiatodon? Vancouverensis, Meek.}

Plate 3, figs. 5 and $5 a$.

Arca Vancourerensis, Meek (185\%), Trans. Albany Institute, iv, 40.

Shell small, longitudinally oblong, moderately gibbous, comparatively thick and strong; anterior margin rounding up from below and meeting the end of the hinge nearly at right angles; posterior side somewhat obliquely truncated; base nearly straight and parallel with the hinge; cardinal area rather narrow; hinge nearly or quite equaling the greatest length of the shell; beaks located a little in advance of the middle, rather small, and incurved; posterior umbonal slopes prominently rounded from the beaks to the postero-basal margin; surface orna- 
mented by small linear radiating costæ, which are crossed by fine concentric striæ and stronger marks of growth. Near the anterior end of the shell, the radiating costre are a little larger and much more widely separated than farther back.

Length, $0.75 \mathrm{inch}$; height, 0.47 inch; breadth or conrexity, 0.40 inch.

I am not well enough acquainted with the hinge of this little shell to be quite sure that it is congeneric with the form on which I proposed to found the genus Grammatodon in the Palæontology of the Upper Mis. souri. One of the casts shows a little of the impression of the hinge in front of the beaks, with apparently four or five small teeth, or denticles, ranging obliquely forward and upward. The posterior muscular impression, as seen in this cast, shows no traces whatever of the lamina connected with that of the posterior adducter, such as exists in Cucullcea.

Locality and position.-Komooks, Vancourer's Island; cretaceous.

\section{Genus? ARCA, Lim.}

\section{ARCA? EqUilateralis, Meek.}

Plate 2, figs. 6 and $6 a$.

Arca (Cucullowa?) equilateralis, Meek (185\%), Trans. Albany Institute, iv, 40.

Internal cast of medium size, equilateral, transversely oblong.oval in form, gibbous in the central and umbonal regions; anal margin obliquely truncated; anterior side subtruncated; base nearly straight along the middle, and rounding up abruptly at the extremities; dorsal outline sloping from the beaks; hinge less than the length of the valves, and parallel to the base; cardinal area comparatively small; beaks central, moderately elevated, and rather gibbous, but somewhat flattened on the outside, and incurved at right angles to the hinge; muscular impressions shallow. Surface (of cast) retaining faint traces of small radiating costæ, or striæ.

Length, 1.68 inches; height, 1.02 inches; breadth or convexity, 0.80 inch.

This species will be readily distinguished from any other with which I am acquainted, resembling it in other respects, by the central position of its beaks. None of the specimens show the hinge, or surface-markings, though faint traces of radiating lines, or striæ, seen on the internal casts, show that it was probably marked by small radiating costæ. It is not easy to decide from the specimens in the collection whether it is an Arca or a Cucullca, or, indeed, with certainty, whether it belongs even to the Arcida. There is on the cast a shallow, obscure depression near each posterior muscular scar; but these depressions seem not so distinct as those always seen on casts of Cucullca, while none of the specimens show the hinge, though there appears to be a small cardinal area.

Locality and position.-Nanaimo?, Varcourer's Island; Cretaceous. 


\title{
Genus INOCERAMLS, Sowerby.
}

\section{INOCERAMUS CRIPSII ? var. SUBUNDATUS.}

\author{
Plate 3, figs. $1,1 a$, and $3,3 a$.
}

Inoceramus Cripsii, Mantell (1822), Fossils South Downs, or Illust. Geol. Sussex, 133, pl. xxvii, fig. 11.-? Goldf., Petref. Germ., ii, 116, figs. 4, a, b.-Zittel (1864), Bivalves of the Gosan Formation, tab. xiv, figs. 1 and 2 (varieties and synon. ?).

? Inoceranus Barabini (part), Morton (1834), Synopsis Org. Rem., 62, pl. 13, fig. 11.

Inoceramus subundatus, Meek.(1861), Proc. Acad. Nat. Sei. Philad., xiil, 315.

Shell (right valve) subovate or truncato-subcircular, rather gibbous ; anterior and posterior margins rounding more or less regularly into the base, so as to form with the latter abont three-fourths of a circle; hinge equaling a little more than two thirds of the entire length of the shell; beak small, rather obtuse near the anterior margin, and rising but slightly above the hinge. Surface ornamented by regular concentric undulations, separated by concave spaces of nearly uniform size, and obscure concentric striæ.

Length, 2.23 inches; height, 1.95 inches; convexity of right valre, 0.70 inch.

I have long been greatly at a loss what disposition to make of shells of this type. In Europe, varions forms more or less nearly like this are generally referred to $I$. Cripsii of Mantell, though it has always seemed to me that several of them are distinct from Mantell's type. Yet we in this country, who have never seen Mantell's original specimen, and only know it from his imperfect figure and very brief description, are greatly at a loss in regard to its exact specific limits.

The question in regard to the proper name to retain for these shells is also further complicated by the fact that Dr. Morton in this country long back described a species, I. Barabini, that is also generally considered a synonym of $I$. Cripsii. Morton, however, included two forms that may or may not be varieties of one species. One of these is represented by figures 2 and $2 a$ of our plate 3, drawn from Morton's original
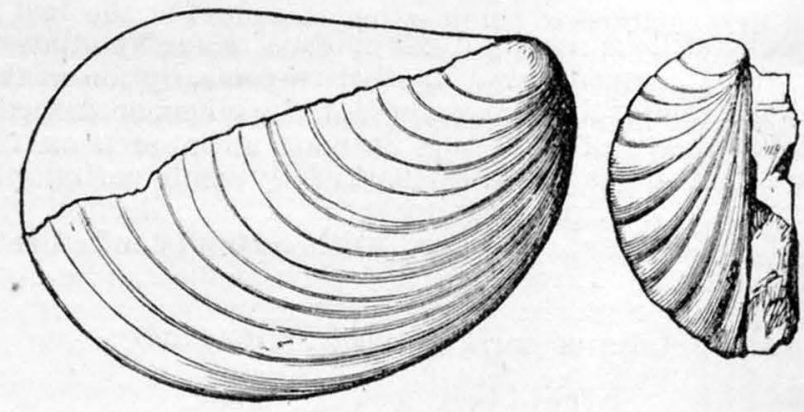

Inoceramus Barabini, Morton.

These figures, were taken from Dr. Morton's type specimen.

specimen, which is an imperfect cast. The other form, represented by the above cut, also made from Dr. Morton's specimen, represents the more elongated form, which is also imperfect. The latter agrees more nearly with Mantell's original so far as we have the means of comparison, but its identity with that species seems at least not very clearly manifest. 
Professor Tuomey concluded that Morton's types represented two distinct species, and named the more elongated form represented by the annexed cut $I$. gibbus, regarding the other as the true $I$. Barabini. At one time, I was inclined to think that this arrangement might be admissible in case Morton had included two types, and that they were both good species. A more attentive reading of Morton's description, however, seems to me to show that he rather regarded the elongated or more oval form as the typical one, not only because he first refers to it in. connection with the name $I$. Barabini, but because he describes that species as "obliquely-oval", which would not be applicable to the rounder form represented by figures 2 and $2 a$ of our plate 3 . That the Vancouver shell under consideration may be identical with the latter, I am inclined to believe; but still the question remains an open one whether either can be properly regarded as $I$. Cripsii.

In originally studying the form under consideration, I proposed to call it $I$. subundatus; but, after seeing how widely $I$. Cripsii is supposed. to vary by European authorities, I have coneluded to refer our shell to it as a variety subundatus. Figure 3 of our plate 3 represents a specimen of somewhat different outline; still I think it belongs to the same species as figure 1 of the same plate.

Locality and position.-Sucia Islands; Cretaceous.

$$
\begin{gathered}
\text { INOCERAMUS - } \\
\text { Plate 1, fig. } 6 .
\end{gathered}
$$

This is also a rather compressed left valve of an ovoid or subcircular shell, with a straight hinge, apparently about equaling half its entire length. It may possibly belong to the same species as the two forms already described, though it possesses stronger and more irregular as well as sharper concentric folds, and has a more obtuse beak, with a more regularly-rounded posterior margin. As it came from a different locality, however, and was found associated with an entirely different group of fossils, the probability is it belongs to a distinct species. Still the specimen is too imperfect to be positively identified with any known species, or described with any degree of confidence as new.

I was at first inclined to think either this shell or the last might possibly be the more compressed valve of Inoceramus Vancouverensis, Shumard; but on examining more carefully his description in the Transactions of the Saint Louis Academy, I find the specimen described by him is also a.left valve, and has a very gibbous, elevated beak. This being the case, none of the forms in the collection before me can, I think, be properly referred to that species.

Locality and position.-Nanaimo, Vaneouver's Island; Cretaceous.

\section{Genus TRIGONIA, Bruguière.}

Trigonia Evansi, Meek.

Plate 2, figs. $7,7 a, 7 b$.

Trigonia Evansi, Meek (185\%), Trans. Albany Inst., iv, 42.-Gabb (1864), California Geo logical Report, i, 189, pl. 25, fig. 17 .

Shell areuate-subtrigonal, gibbous anteriorly, contracted, cuneate, and slightly gaping behind; ventral margin deeply rounded in outline in the middle; anterior side very short, rounding up nearly vertically No. $4-6$ 
to the beaks; posterior extremity quite narrowly rounded, or subtrun cated; dorsal margin very concave in outline, and sharply carinate or erect along its whole length; escutcheon lance-oval, being widest anteriorly, where it is distinctly concave on each side of the carina formed by the erect dorsal margins of the valves, bordered along each side by a low ridge commencing very narrow at the beaks and widening gradually posteriorly, with a well-defined narrow mesial sulcus along the entire length of each of these ridges; concave space within these ridges ornamented by small, nearly smooth, transverse costæ, extending up to the dorsal margin; beaks nearly terminal, rather narrow, erect, and strongly incurved at nearly right angles to the longitudinal axis of the valves. Surface ornamented by from eighteen to about twenty-two angular transverse costæ that terminate abruptly above, along the low ridge bounding the escutcheon; costæ sometimes slightly crenated, particularly those on the more gibbous anterior region; lines of growth moderately distinct. Internal cast showing only obscure traces of the costæ; posterior muscular impression deep; pallial line moderately distinct.

Length, 2.65 inches; height, about 1.86 inches; convexity, 1.70 inches.

In its general outline as well as in the nature of its costæ, this shell resembles T. limbata, d'Orbigny (Paléont. Fr. Terr. Orét., iii, pl. 298). It may be readily distinguished, however, not only by its less prominently-rounded anterior ventral region and more erect and more anterior beaks, but by its more arcuate dorsal outline, and especially by having along each side of its escutcheon a depressed, longitudinallysulcated ridge, upon which the costæ do not pass. In the latter character, it agrees more nearly with $T$. crenulata, Lamarck, and T.aliformis, Parkinson; but it differs from these species too decidedly in form and the nature of its costæ to require detailed comparisons.

It is almost certainly the same shell that was referred by Mr. Etheridge among Mr. Hector's collections from Nanaimo, to T. Emoryi, Conrad (pl. iii, fig. 2, $a, b, c$, United States and Mexican Boundary Survey Report). It is, however, certainly very distinct from that species, not only in form and in its decidedly less crenate costæ, but more particularly in having a smooth, longitudinally sulcate, depressed ridge along each side of its escutcheon, not crossed by the costæ. Its costæ are likewise less numerous and more prominent.

Locality and position.-Cretaceons beds, at Nanaimo, Vancouver's Island.

Mr. Gabb states, in the California report, that it is common in division A of the survey of that State, at Tuscan Springs, Tehama County; Chico Creek, Butte County; Curry's, south of Mount Diablo; Benicia; Martiñez; Rancho de San Luis Gonzaga, Pacheco's Pass; Jacksonville and Siskiyou Mountains, Oregon. Mr. William P. Blake also presented to the Smithsonian Institution some masses of rock from Crooked River, Oregon, containing beautiful, sharpl 5 -defined moulds of this species.

\section{Genus PROTOCARDIA, Beyrich.}

Protocardia scitula Meek.

Plate 3, figs. 4 and $4 a$.

Cardium soitulum, Meek (1857), Trans. Albany Institute, iv, 40.

Shell very small, cireular or subquadrate, gibbous; anterior margin rounded; posterior side subtruncated; base slightly rounded; beaks nearly central, gibbous, incurved, and moslerately elevated; surface 
marked by exceedingly fine, obscure, closely-arranged, concentric striæ, which are crossed on the posterior umbonal slopes by a few stronger radiating lines, extending from near the beaks to the posterior and postero-basal margins. Hinge and interior unknown.

Length and height, 0.15 inch; breadth or convexity, 0.12 inch.

This delicate little shell resembles Cardium subquadratum of Evans and Shumard, but is much more gibbous, and more rounded in outline, than specimens of that species of its own size. It also differs in having mueh more distinct radiating lines on its posterior side; those on Cardium sub. quadratum being almost entirely obsolete. In the roundness of its outline, as well as in the gibbous character of its valves, it approaches Cardium rarum of Evans and Shumard; still, its posterior margin is more truncated, and its radiating lines much more distinct. It likewise differs from both of these species in being a much smaller shell than either of them; though it may be the young of even a larger species.

Mr. Gabb has described two Cretaceous species of this group in the California Geological Reports, nnder the names Protocardia Placerensis and $P$. translucida, that may, one or both, be related to this, though they differ in outline.

Locality and position.-Komooks, Vancourer's Island; Cretaceous.

\title{
Genus CYPRIMERIA, Comrad.
}

\section{Cyprimeria? tenuis, Meek.}

\author{
Plate 2, figs. $5,5 a$, and $5 b$.
}

Dosinia? tenuis, Meek (1861), Proceed. Acad. Nat. Sci. Philad., xiii, 315.

Shell circular or slightly oval, extremely thin, and much compressed; lateral and basal margins regularly rounded, very thin, and sharp; beaks small, compressed, central, projecting little above the dorsal margin; lunule small and rather deep; surface marked by fine concentric striæ.

Length and height each 1.26 inches; convexity about 0.22 inch.

I have merely placed this species provisionally in the genus Cyprimeria, not having seen specimens showing either the hinge or other internal characters. It has much the appearance of a Lucina, but some of the internal casts appear to show that its anterior muscular impressions are not as in that genus, while they also give indications of a double oblique tooth just in front of the beaks, more nearly as we see in Oyprimeria.* It is a rather common species, and will be readily identified by its circular compressed form and extreme thinness. It is closely allied, so far as regards general appearance, to Artemis lentioularis of Forbes from the Cretaceous at Pondicherry, Southern India (Trans. Geol. Soc. Lond., vol. vii, pl. 18, fig. 7).

Locality and position.-At several places near Nanaimo, Vancouver's Island, and on New Castle Island; Cretaceous.

\footnotetext{
* In the cast represented by figs. $5 a$ and $5 b$, the tooth does not show its double character so clearly as others.
} 


\section{Genus PHOLADOMYA, Sowerby.}

Pholadomya subelongata, Meek.

Plate 2, figs. 1 and $1 a$.

Pholadomya subelongata, Meek (1857), Tran s. Albany Institute, iv, 42.

Shell transversely oblong-oval, rather elongated and depressed; valves gibbous, particularly in the umbonal region; anterior side very short and abruptly rounded; posterior side rounded or subtruncated, and more or less gaping; basal margin forming a broad semi-elliptical curve, sometimes nearly straight along the middle; dorsal margin concave in outline, so as to be nearly parallel with the base; false area rather well defined just behind the beaks, but becoming obsolete a little further back; beaks nearly terminal, depressed, and incurved. Surface of each valve ornamented by from sixteen to twenty-five small radiating costr, most of which pass from the beaks obliquely backward and downward to the postero-basal margin, those near the anterior end being much more distant than the others, and separated by spaces from four to six times their own breadth. Small concentric wrinkles mark the surface in the other direction, giving the costæ a slightly crenulated or subnodose appearance.

Length, 1.60 inches ; height (at the beaks), 0.75 inch; breadth or convexity, 0.69 inch.

In form, this species resembles somewhat rarieties of Pholadomya foliacea, Agassiz (Etud. Crit. sur les Moll., p. 102, pl. 7, particularly fig. $8)$, but its beaks are not near so oblique, and located farther back. Its costæ are also smaller and more defined as well as more numerous, while its dorsal outline is more concave.

Locality and position.-Nanaimo, Vancouver's Island, also on New Castle Island ; Cretaceous.

\section{Genus GONIOMYA, Agassiz.}

Goniomya borealis, Meek.

Plate 2, fig. 2.

Pholadomya (Goniomya) borealis, Meek (1857), Trans. Albany Iust., iv, 41.

Shell transversely subovate or oblong-ovate, moderately compressed; anterior side rather abruptly rounded; posterior extremity truncated; cardinal margin sloping from the beaks, the anterior slope being more abrupt than the other; base forming a broad gentle curve, rounding up more gradually in front than behind; beaks moderately prominent, and located about half-way between the middle and the anterior end. Surface ornamented by from twenty to twenty-five small costæ, which pass down the sides of the shell from the dorsal margin behind and in front of the beaks, so as to meet at acute angles along an imaginary line extending from each beak obliquely backward and downward to near the middle of the base. A few of those near the posterior and anterior ends reach the base before uniting to form an angle. Obseure lines of growth are also seen on portions of the surface.

Length about 1.70 inches; height, 1.12 inches; breadth, 0.65 inch.

The only specimen of this species in the collection is imperfect, being somewhat distorted by pressure, and broken at the extremities. The 
eurves of its lines of growth, however, give a tolerably correct idea of its outline, and show that its posterior side is rather distinctly truncated. This end also seems to have been gaping, while the other extremity has the appearance of being closed. The substance of the shell is evidently very thin; and it is probable unworn specimens will show the surface to be grannlar, as usual the case in this and allied genera.

In its general appearance, this species resembles Goniomya americana, described by Dr. Hayden and myself from the Upper Cretaceous rocks of the Upper Missouri (see Proc. Acad. Nat. Sci. Philad., viii, 81), but it is proportionally deeper from the beaks to the base, and differs in having the costæ on the posterior side of its valves curving forward, instead of being directed obliquely backward. Other differences will probably be seen on comparing better specimens.

Lcality and position.-Nanaimo, Vancouver's Island; Oretaceous.

\section{Genus THRACIA, Leach.}

Thracia? occidentalis, Meek.

Plate 2, figs. 3 and $3 a$.

Thracia? occidentalis, Meek (1857), Trans. Albany Inst., iv, 43.

Shell elliptical, moderately compressed, thin and fragile; right valve apparently a little more convex than the other; extremities rather narrowly rounded; outline of base forming a broad 'semi-elliptic curve; dorsal margin sloping a little in front of the beaks, and less distinctly behind them; beaks nearly central, small, compressed, and not much elevated; postero-dorsal region compressed behind the posterior umbonal slopes. Surface (of worn specimens) showing obseure wrinkles of growth.

Length about 2.08 inches; height, 1.25 inch; breadth, 0.52 inch.

As none of the specimens of this and the following species are in a condition to show the hinge, pallial line, or muscular impressions, it is only provisionally that they have been placed in the genus Thracia.

Locality and position.-Nanaimo, Vancouver's Island; Cretaceous.

Thracia? subtruncata, Meek.

Plate 2, figs. 4 and $4 a$.

Thracia 9 subtruncata, Meek (1857), Trans. Albany Institute, iv, 44.

Shell transversely subelliptical or subovate, thin and moderately compressed, the right valve being a little more convex than the other; anterior side rather narrowly rounded; posterior extremity subtruncated; basal margin forming nearly an elliptic curve, but rounding up more gradually in front than behind; cardinal margin sloping with a slightly convex outline in front of the beaks, and nearly horizontal behind them; beaks subcentral, small, compressed, and but moderately prominent. Surface (of worn specimens) showing traces of rather distinct lines of growth. From immediately behind the beaks, there is (in internal casts) a distinet depression passing obliquely backward and downward just back of the posterior umbonal slope of each valve. Hinge and other internal characters unknown.

Length, 1.84 inches; height, 1.14 inches ; breadth about 0.50 inch.

It is possible that this may not be distinct from the last, but, judging from the specimens yet seen, I am inclined to think these two forms belong to different species. That now under consideration differs from 
the last in having the posterior side rather distinctiy truncated, instead of being narrowly rounded. It seems to be also a proportionally shorter shell, while the oblique depressions (in casts) behind its beaks are deeper and more defined.

Locality and position.-Same as last.

\section{GASTEROPODA. \\ Genus DENTALIUM, Linnæus. \\ Dentalium Komooksense, Meek. \\ Plate 3, fig. 6.}

Dentalium Komooksense, Meek (1857), Trans. Albany Institute, iv, 44.

Shell of medium size, slightly arcuate, and rather distinctly tapering, comparatively thin; section circular. Surface ornamented by elevated longitudinal lines or small costæ, of which about sixteen may be counted near the smaller end, where they about equal the depressions between them in breadth; farther up (toward the larger end), there is between each two of these costæ an intermediate smaller one developed. On following all these costæe to near the middle of the shell, they are seen all to become of nearly uniform size, less distinctly defined, and proportionally more closely arranged. The lines of growth are very fine, obscure, and pass around rather obliquely.

Diameter near the smaller end, 0.05 inch, and increasing to $0.10 \mathrm{inch}$ in a length of 0.50 inch.

This species is nearly related to D. gracile of Hall and Meek (Memoirs Am. Acad. Sci. and Arts, Boston, vol. 5, p. 393), from which it may be distinguished by its thinner shell and more slender form as well as by its less distinct lines of growth.

Locality and position.-Nanaimo?, Vancouver's Island; Cretaceous.

\section{CEPHALOPODA.}

\section{Genus BACULITES, Lamarck.}

\section{Baculites Chicoensis, Trask?}

Plate 4, figs. 2 and $2 a, b, c$.

Baculites Chicoensis, Trask (1856), Proceed. San Francisco Acad. Nat. Sci., 85, pl. 2, fig. 2.-Gabb (1864), Report Geol. Survey California, vol. i, 80, pl. 14, figs. 27, 29 , and $29 a$, and pl. 17 , tigs. 27 and $27 a$.

Baculites inornatus, Meek (1861), Proceed. Acad. Nat. Sci. Philad., xiii, 316.

Compare Baculites ovatus, Say.

Shell apparently attaining nearly a medium size, straight, very gradually tapering, with a regularly ovate section, the antisiphonal side being a little more broadly rounded than the siphonal;* lateral sinuses of the lip

\footnotetext{
* Until recently, the outer or siphonal side of the Ammonitoid forms has been generally called the dorsal side, and the inner the ventral. From the position of Nautilus in its shell, however, it has been, with good reason, inferred that the outer side of the Am. monites is really the ventral side. By analogy, we may also infer that the siphonal or narrow side of the Baculites is the ventral side. I have therefore so considered it, and, to avoid confusion, described what used to be called the dorsal lobe as the siphonal lobe, and merely referred to the lateral lobes and sinuses on each side as "first and second lateral lobes and sinuses". I have also applied the same nomenclature to the Ammonites, merely counting the number of the lateral lobes and sinuses, whether many or few.
} 
deep and nearer the antisiphonal side; siphonal projection of lip rather long and linguiform, while that of the dorsal side is nearly semicircular in outline. Surface entirely smooth, or with only obscure lines of growth, curving parallel to the projections and sinuses of the lip.

Septa moderately approximate but not crowded; lobes and sinuses on opposite sides of the shell sometimes differing slightly in their details. Siphonal lobe shorter than the first lateral, and a little more than onethird wider, provided with two rather large, widely-separated terminal branches, with each about six or seven small, short, unequal subdivisions, some of the larger of which are bifid and others trifid. First lateral sinus of about the size of the first lateral lobe, and divided at the extremity into two short, subequal, trifid, terminal branches, with sinuous and obtusely digitate margins. First lateral lobe a little longer than, and about as wide as, the first lateral sinus; on one side of the shell sometimes ornamented by five short, nearly equal, palmatelyspreading branches, with from four to five digitations each (see fig. $2 \mathrm{c}$ ), while on the other it is sometimes divided at the extremity into four unequal branches (see fig. $2 b$, plate 4 ), one of which is considerably longer than the others, and more or less distinctly bifid and digitate. Second lateral sinus of nearly the same size and form as the first. Second lateral lobe a little shorter than the siphonal lobe, and about two-thirds as wide, nearly equally divided at the extremity into two short, spreading branches, of which the one on the siphonal side is provided with four short, unequal, digitate subdivisions, and the other into two very unequal branchlets, the larger of which has four or five digitations. Antisiphonal lobe about half as long as the adjacent side of the second lateral lobe, near half as wide a long, and ornamented by four or five digitations on each side.

The largest fragment in the collection measures 1.49 inches in its greater diameter, and 1.13 inches in its smaller, and, judging from its very gradual taper, it appears to have been, when entire, as much as 12 or 15 inches in length.

At the time I proposed the name B. inornatus for this species, I only knew Dr. Trask's B. Chicoensis from his figures and deseription of a very small specimen, giving searcely any idea of the septa of what is now known to be a very young individual of his species. Since seeing Mr. Gabb's figures of the larger specimens of the same shell from the original locality, I am led to think that our Sucia Island specimens may belong to the same species. Of this, however, I cannot be positively sure without a better series of specimens for comparison, particularly as our specimens differ somewhat in the details of their septa from Mr. Gabb's figures, and are still considerably larger than those illustrated. by him. In its septa, it agrees more or less nearly with B. grandis, $\mathrm{H}$. and M., and B. ovatus, Say, but it seems never to attain a size approaching that of the adult shell of either of these forms, while it is destitute of the lateral undulations of the same, so far as can be determined from our specimens, though Mr. Gabb figures one individual that he refers to Dr. Trask's species with these undulations well developed. It is worthy of note, however, that his specimen showing this character differs materially in other respects from our specimens, as well as from the other referred by him to the B. Chicoensis.

Locality and position.-Cretaceous of Sucia Islands. 
BacUlites occidentalis, Meek.

Plate 4, figs. $1,1 a, b$.

Baculites ovatus (Say?), Meek (1857), Trans. Albany Inst., iv, 48. Baculites occidentalis, Meek (1861), Proceed. Acad. Nat. Sci. Philad., xiii, 316.

Shell attaining a medium size, very gradually tapering; section subtrigonal, excepting near the smaller end, where it is more nearly ovate; antisiphonal or broader surface flattened so as to give its lateral margins a more or less angular appearance; sides converging with slightly convex outlines from these angles to the narrowly rounded or obtusely angular siphonal margin; aperture subtrigonal, with the antisiphonal margin of the lip nearly semicireular, and that of the siphonal side much longer and somewhat cuneate-sublinguiform, while the lateral sinuosities are rounded with a long, nearly straight, oblique margin on the siphonal side. Surface ornamented with small, obscure, regular undulations, extending across from the dorso-lateral angles to or beyond the middle of each side, with a regular curve parallel with the margins of the lateral sinuosities of the lip. Fine rather regular but obscure lines of growth also run parallel to the curves of the lip margin.*

Septa neither crowded nor very distant. Siphonal lobe somewhat shorter than the first lateral lobe, and twice as wide, provided with two rather large, widely-separated terminal branches, each of which is bifid, the subdivisions being armed with numerous unequal, rather sharp dig. itations. First lateral sinus of abont the breadth of the siphonal lobe, near one-third longer than wide, and deeply divided at the extremity into two nearly equal branches, each of which is tripartite, with short obtuse sinuosities and digitations. First lateral lobe as long as the second, but only about two-thirds as wide, and provided with three principal branches on each side, the two terminal of which are a little larger than the succeeding lateral divisions, and each armed with from six to eight or nine small unequal branchlets and digitations. Second lateral sinus a little broader than the first, but in other respects very similar to it, excepting in having its corresponding branches on opposite sides. Second lateral lobe nearly as wide as long, its antisiphonal side being only about half as long as the other, owing to the shortness of the antisiphonal sinus, provided at the extremity with four palmately-spreading branches, the two inner of which are larger than the others, rather widely separated, and each irregularly trifid and more or less digitate. Antisiphonal lobe about half as long as the longer side of the second lateral lobe on each side, lance-ovate in form, and provided with some five or six digitations on each lateral margin, one of which near the middle of each side is considerably longer than the others.

The specimens yet known being all imperfect, it is not possible to give accurate measurements from them; though, as nearly as can be determined from the taper of the longest fragments in the collection, the average length of a specimen measuring 1.45 inches in its greater diameter at the larger end would appear to have attained a length of 12 to 15 inches.

Although I continue to regard this form as being speeifically distinct from the last, I am prepared to believe that more extensive collections may yet show it to be only a variety of that species. So far as yet

* On each side of the specimen represented by fig. 1 of plate 4 , there is a curious backward flexure of the lines of growth along an imaginary line near each dorso-lateral angle as seen at $(a)$ of the figure mentioned. As this character, however, is only seen on this one specimen, it is doubtless due to some accident. 
known, however, it differs in the details of its septa, while in the peculiar flattening of its dorsal or antisiphonal side it differs not only from the last but from any other species of the genus known to me. I noticed this peculiarity in the specimen first referred provisionally to Say's $B$. ovatus, but supposed it due to some accident. The collections subsequently obtained, however, show that it is not due to accidental pressure. It must be remembered, however, that individuals of the same species in this genus are subject to some variations of form as well as of the details of the septa; while they often present so few characters apon which to found species that their proper classification is generally very difficult, excepting to those who would refer all such forms throughout the world to the single species B. anceps of Europe. This form bears somewhat the same relations to the last that $B$. compressus, Say, bears to his $B$. ovatus, its septa being very like those of the former; so far as known, however, it seems never to be so compressed as $B$. compressus at any stage of growth.*

Locality and position.-Same as last.

\section{Genus HETEROCERAS, d'Orbigny.}

Heteroceras Cooperi, Gabb (sp).

Plate 3, figs. 7 and $7 a$.

Ammonites ? Cooperi, Gabb (1864), California Geol. Report, i, 69, pl. 14, figs. 23 and $23 a$.

Of this fossil, there is in the collection but a single non-septate frag : ment, measuring 3.50 inches in length and about 1.90 inches in its greates ${ }^{t}$ breadth; the section being slightly oval. It is evidently a part of a spiral shell, with rounded disconnected whorls; and, judging from its curve, it must have possessed a much larger umbilical space than is seen in Turrelites. As it is very much larger than any known Helicoceras, it would seem to have belonged to the non-septate part of a shell allied to Heteroceras. Its surface is ornamented by moderately distinct annular costæ, which pass around rather obliquely. Two rows of nodes also occur on the outer or dorsal side, at which points the costæ usually bifurcate.

I refer this shell with much doubt to the species described by Mr. Gabb under the name Ammonites? Cooperi, which it seems probable was founded on a fragment of a Heteroceras. Mr. Gabb referred his species doubtfully to the genus Ammonites, as he had only mere frag. ments for study.

Locality and position.-Komooks, Vancouver's Island : Cretaceous.

\section{Genus AMMONITES, Brnguière.†}

Anmonites NewberRyanus, Meek.

Plate 4, figs. $3,3 a$, and $3 b$.

Ammonites Newberryanus, Meek (1857), Trans. Albany Institute, iv, 47 (not A. Newberryanus, Gabb. (1864), Geol. Report California, i, 61, pl. 27).

Shell discoid, moderately compressed, rounded on the periphery; umbilicus of moderate depth, less than one-third the greater diameter

\footnotetext{
* Since this was written I have ascertained that large specimens of $B$. compressus show a tendency to present a similar subtrigonal section (see Invert. Palæont. Upper Mo., 403), from which it would appear that this Vanconver form may be more nearly related to $B$. compressus than has been suspected.

$\uparrow$ None of the species here described belong properly to the genus Ammonites, as restricted by late investigators of the family Ammonitida. As the Cretaceous groups of
} 
of the shell; volutions five and a half or more, increasing very gradually in size, diameter from ventral to dorsal side nearly or quite equaling their transverse breadth-all rather deeply embracing, so as to conceal more than half of each inner turn. Surface ornamented by distinct rounded costæ, which oceasionally bifurcate near the umbilicus and about half-way across toward the periphery, in crossing which they curve slightly forward; depressions between the costæ generally about equaling the latter in size, but, at intervals of about five or six times to each turn, a deep sulcus or constriction is seen on internal casts, produced by the occasional thickening of the lip, at regular intervals of about every fifth of each turn. A single row of small transverselyelongated nodes surrounds the umbiliens.

Septa deeply divided into six or seven principal lobes on each side, which diminish regularly in size from the first lateral lobe to the umbilicus. Siphonal lobe about the size of the first lateral sinus, oblong in form, and provided with three principal branches on each side, the two terminal of which are larger than the others, and each irregularly subdivided into two or three small branchlets and a few sharp digita. tions. First lateral sinus deeply divided at the extremity into two subequal parts, and provided on each side behind these with two or three irregular alternating lateral branches-the two terminal divisions being: much larger than the others, and each irregularly tripartite, with sinuous and digitate margins. First lateral lobe about the size of the first lateral sinus, palmately divided at the extremity into three large irregular branches, with each three or four sharp unequal digitations at the end ; while above these terminal divisions, the sides of the lobe are each ornamented by two or three smaller alternating sinuate lateral branches. Second lateral sinus smaller than the first lateral lobe, and having on each side two or three irregular alternating lateral divisions, while the extremity is divided into two unequal terminal branches, each of which is again divided into two or three small branchlets, with sinuous margins. Second and third lateral lobes much smaller than the first lateral, but somewhat similarly branched, their divisions being, however, proportionally shorter. The three or four remaining lobes are very small, a little oblique, and merely digitate.

The specimen from which the foregoing description was made out measures 2.28 inches in its greatest diameter and 0.90 inch in convexity. As it consists entirely of septate whorls, it is probable that the outer volutions of adult individuals may vary somewhat in their external ornaments, as well as in the details of their septa, from the speeimen under examination.

In form and other external characters, this species is nearer like A. mutabilis of Sowerby (Min. Couch., iv, 145, pl. 405) than any other shell with which I am acquainted. I have not had an opportunity to see the septa of that species; but if it is, as some think, not distinct from A. Koenigii, Sowerby, our Vancouver species may be readily distinguished by its more deeply-lobed septa.

Named in honor of Prof. John S. Newberry, State geologist of Ohio, and professor of geology in the School of Mines, Columbia College, New York.

Locality and position.-Same as last.

these Cephalopods have not yet been classified, however, in accordance with the prevalent modern views, and I have not the necessary material at hand to determine the exact relations of our species to some of the proposed genera, I have concluded to leave part of them, for the present, under the old genus 4 mmonites, as understood in its most comprehensive sense. 


\section{AmMonites Complexus?, var. SuOHansis.}

Plate 5, figs. 2 and $2 a, b, c$.

Ammonites complexus, Hall and Meek (1856), Mem. Am. Acad. Arts and Soi. Boston, $r$, (new series), 394, pl. 1, fig. 1, $a-f$.

imntonites complexus, var. Suciaensis, Meek (1861), Proceed. Acad. Nat. Ssi. Philad., xiii, 317.

Ammonites Suciaensis, Gabb (1869), California Geol. Report, i, 133, pl. 21, figs. 11 and $11 a, b$

Shell attaining a moderate size, discoid, rounded on the periphery;. umbilicus shallow-erateriform, about half as broad as the outer volution from the dorsal to the ventral side, and showing nearly one-third of each inner turn; volutions apparently about five or six, increasing rather gradually in size, last one very slightly compressed on the sides, and rounding to the periphery and umbilicus, all deeply embracing. Surface ornamented by transverse costæ, which, in the very young shell, appear to be merely little elongated nodes near the umbilicus, but in a more advanced stage of growth cross the sides, and pass straight over the periphery as narrow low ribs, separated by wider flattened depressions, while on the outer turn of large shells they seem to be nearly ob. solete; between each two of those that extend inward to the umbilical side, there is usually one, or sometimes two, that become obsolete before reaching the inner margin, while those that extend entirely across swell a little near the umbilicus so as to show a tendeney to develop obseure, elongated nodes.

Septa profoundly divided into slender, variously-branched, and digitate lobes and sinuses. Siphonal lobe nearly as large as the first lat. eral lobe, and ornamented on each side by four branches, which inerease in size, and become more subdivided toward its extremity, the two terminal divisions being considerably larger than the others, and each divided into four or five unequal digitate, spreading branchlets. First lateral sinus as large as the siphonal lobe, about one-third longer than wide, slender and flexuous near the base, and very deeply divided above into two subequal slender branches, each of which is subdivided so as to form three or four unequal, more or less bifurcating, and deeply sinuous branchlets. First lateral lobe one-third longer than wide, and ornamented at the extremity by three great spreading, nearly equal, branches, each of which is subdivided into three or four principal branchlets, with numerous smaller digitate subdivisions. Second lateral sinus as long as the first, but narrower, and very similarly divided. Second lateral lobe nearly two-thirds as large as the first, and closely resembling it in its branches and subdivisions. Third lateral lobe about half as large as the second, with somewhat similar but less deeplydivided branches.

There are three or four other much smaller lobes between the third lateral lobe and the umbilicus, which are very oblique, and each more or less distinetly trifid and digitate at the extremity.

I have endeavored to give a full and detailed description of this shell, because, after a very eareful comparison, I am left in doubt whether it should be regarded as a variety of $A$. complexus (Hall and Meek) or as a distinct species. It certainly is a much more eompressed shell, the volutions of $A$. complexus being nearly twice as wide transversely as from the dorsal to the ventral side, while these two diameters of the whorls in the form before me are nearly equal. Differences of this kind, however, are not generally reliable as a means of distinguishing species in this group; though the few specimens of $A$. complexus yet brought 
from Nebraska, as well as those found in New Jersey, do not show any essential variations in this respect.

In the relative size, number, and arrangement, as well as in the mode of branching, of its lobes and sinuses, the shell under consideration agrees very nearly with authentic specimens of $A$. complexus; though in the details of the divisions of its septa there are differences from those of that form. Still these differences, as may be seen from the figure given on plate 5 , seem to be of such a nature that they may be due to different degrees of development in the specimens compared; the feew individuals of $A$. complexus yet found, either at the original locality or in New Jersey, being smaller than those of the form under consideration with which I am comparing them. That first figured by Professor Hall and the writer is not in a condition to give a clear idea of the septa of the Nebraska shell.

In the lobes and sinuses of its septa, this species is also very closely allied to $A$. Gollevillensis, d'Orbigny ( $=A$. Lewisiensis, d'Orb., not Sowerby). It is a more gibbous shell, however, and differs in having its costæ developed entirely across to the inner side of its whorls, while its periphery is completely destitute of the longitudinal groove so characteristic of d'Orbigny's species.

It is also nearly related to $A$. Egertonianus, Forbes, from the Cretaceons of India, but its volutions are less compressed, its costæ smaller, and its septa different in some of their details, particularly in the arrangement of the small inner lobes near the umbilical margins.

The largest specimen in the collection is from Sucia Islands. It is an internal cast, and has its outer turn so much worn as to obliterate much of the details of the lobes and sinuses, as may be seen by fig. $2 b$ of plate 5. The inner turns, however, when separated, show the septa very clearly. It consists entirely of septate whorls, the non-septate portion having been broken away. In its greatest diameter, it measures 4.60 inches, and 1.90 inches in breadth. Others (retaining most of outer chamber) measure about 3.15 inches in their greater diameter.

Locality and position.-Komooks, Vancouver's Island, and at Sucia Islands ; Cretaceous.

\section{Genus PLACENTICERAS, Meek.}

\section{Plaoenticeras? Vancouverense, Meek. \\ Plate 6, fig. 1, $1 a, 1 b$, and $1 c$.}

Ammonites Fancouterensis, Meek (1861), Pruceed. Acad. Nat. Sci. Phila., xiii, 317.

Shell discoidal; volutions inereasing rather gradually in size, strougly compressed on the sides, and flattened on the narrow periphery, nearly twice as broad from the peripheral to the umbilical side as the transverse diameter, and rather deeply embracing; umbilicus of moderate depth, and small, or rather less than half as wide as the greater diameter of the outer whorl; aperture (as nearly as can be determined from a section of one of the whorls) compressed-subcordate. Surface ornamented by a row of compressed nodes along each margin of the periphery, and another of smaller size around the umbilicus of each side; about twenty of the first and ten of the latter may be counted on each side of an entire turn. The flattened sides between the peripheral and umbilical rows of nodes are provided with obscure, slightly-arching, transverse costæ, one of which extends from each of the umbilical nodes toward the peripheral margin; but all become obsolete before reaching it, at least on the outer turn. Between each two of these principal 
costæ, one or two more very obscure ones are seen, which do not reach either the peripheral or umbilical margin.

The septa are strongly undulating, and irregularly divided into very unequal principal and subordinate lobes and sinuses on each side. Siphonal lobe comparatively small, and prorided with three short branches on each side, the two terminal of which are a little larger than others, slightly spreading, and merely a little dentate on their margins ; first lateral sinus about twice as large as the siphonal lobe, and very unequally divided into three branches, the outer one of which is largest, and truncated at the end, with four short, nearly simple, subdivisions, while the middle branch is smallest, with merely deeply sinuous margins, and the third one is tripartite and directed nearly inward toward the umbilical side; first lateral lobe small, slender, veryoblique, bipartite, with unequal bifid terminal branches; second lateral sinus scarcely larger than the oblique branch on the inner side of the first, very oblique, with an extremely contracted body, and two or three alternately-arranged, short, sinuous branches on each side ; second lateral lobe longer than the first, somewhat arcuate, with a slender body, a trifid extremity, and three or four short, alternately-arranged, slightly dentate, lateral branches; third lateral sinus smaller than the second, with a proportionally less contracted body, and about three short, alternating, unequal, nearly simple, lateral branches, and a small, simple, subglobose, terminal division; third lateral lobe projecting a little beyond the second, and almost exactly like the first, excepting that its corresponding branches are on the opposite sides; fourth lateral sinus extremely broad, or more than equaling the breadth of the first, which it also nearly equals in length, slightly divided at the end into two nearly equal, short, broad divisions, with more or less sinuous margins ; fourth lateral lobe nearly as large as the third, but owing to the undulating arrangement of the whole series, much less prominent, divided at the end into two short, equal, bifid branches, with obscurely dentate margins; fifth, sixth, and seventh lateral lobes of nearly equal size, and scarcely half as long and wide as the fourth, with merely dentate extremities and lateral margins-all separated from each other by lateral sinuses of about the same size.

I was at one time of the opinion that the three divisions of the septa here deseribed as the first, second, and third lateral lobes formed, together with the great undulation of the suture with which they conneet, one enormously-developed first lateral lobe, which would also make the very broad sinus I now view as the fourth, the second lateral sinus. It now seems to me, however, from analogy, on comparison with the sutures of Placenticeras placenta (= Ammonites placenta, DeKay), that the view taken in the above description of the septa is the proper one.

The specimen from which the figure and description of this species were made out consists of about one-half of one volution, most of which is non-septate. When entire, the shell must have measured not less than 4 inches in its greatest diameter, and about 1.13 inches in convexity. Locality and position.-Komooks, Vancouver's Island ; Cretaceous.

\section{Genus PHYLLOCERAS, Suess.}

\section{Phylloceras? RAmosus, Meek.}

\section{Plate 5, figs. $1,1 a$, and $1 b$.}

Ammonites (Scaphites?) ramosus, Meek (1857), Trans. Albany Institute, vol. iv, 45.Gabb, (1864) Geological Report of California, vol. i, 65, pl. 11, figs. 12 and $12 a$; and pl. 12 , fig. $12 b$.

Shell oval-discoid in form, compressed, very thin and fragile; narrowly rounded on the periphery; umbilieus very small, but not enti rely elosed; 
volutions increasing rather rapidly in dorso-ventral diameter, and more gradually in convexity, compressed so as to be nearly flat on the sides, but rounding a little into the immediate umbilieus and to the periphery, each so deeply embracing as to hide all the preceding ones. Surface ornamented by numerous fine, regular, nearly simple, transverse lines, which increase very gradually in size from the inner to the outer whorls, and in crossing the sides curve first gracefully forward near the umbilicus, then, after passing the middle, areh slightly backward, and again a little forward in passing over the periphery.

Septa extremly complex, being crowded together and very deeply divided into variously-branched lobes and sinuses, which diminish regularly in size from the peripheral margin to the umbilicus. Siphonal lobe covering between one-half and one-third as much space as the first lateral lobe, and having on each side three branches, of which the two at the extremity are mueh larger than the others, and each divided nearly to its base into two unequal slender branchlets, with several smaller subdivisions and sharp digitations; first lateral sinus a little larger than the siphonal lobe, very oblique at its base, and profoundly divided at its extremity into two large, unequal, slender branches, which are variously subdivided and sinuous; first lateral lobe slender, but spreading its deeply-divided branches over a surface nearly twice as large as that occupied by the first lateral sinus, ornamented at the extremity by three large, unequal, spreading branches, which are each irregularly subdivided into from four to six or seven branchlets, with numerous pinnæ and smaller digitations; second lateral sinus nearly half as large as the first lateral lobe, contracted and oblique below, and having at its extremity four unequal divisions, three of which are trifid and the other bifid, and all provided with numerous irregular subdivisions with sinuate margins; second lateral lobe less than half as large as the first, and divided into abont seven principal alternating branches, of which the three nearest the extremity are larger than the others, and each again divided into two more or less sinuọus and digitate parts.

The remaining three or four lobes diminish regularly in size, and become less branched toward the umbilicus; the third, fourth, and fifth being palmately divided at the extremity into five, four, and three short, unequal branches, while those nearer the umbilicus are more nearly simple, or only ornamented by a few small digitations.*

In the structure of its septa, this is one of the most complex species I have ever seen; the surface of the cast being so completely covered by the numerous \&lender branches of the lobes and sinuses as to render it exceedingly difficult to follow their various ramifications. Yet, from all analogy, they are doubtless even more complex in the outer whorls of large adult specimens, since that before me measures only 1.90 inches in its greater diameter, and 0.53 inch in convexity; while impressions left in the matrix of some of the specimens show that some individuals are not less than five inches in their greater diameter.

In form and surface-markings, it is much like Ammonites Velledwe of Michelin, as figured by d'Orbigny on plate 82 of his palæontology of France, vol. $i$ (Cretaceous), though it is more compressed. Yet this slight external difference, if not accompanied by well-defined peculiarities in the lobes and sinuses of the septa, would not be sufficient to dis-

* The typical specimen does not show the lobes and sinuses of the septa very clearly beyond the siphonal and first laternl lobes and the first lateral sinus; but Mr. Gabb's California specimen, which did not show the siphonal lobe, exhibits all of the other lobes and sinuses very clearly. 
tinguish these forms. When we compare the septa, however, they are at once seen to present marked differences, such as are clearly incompatible with specific identity, if d'Orbigny's tigures are accurately drawn. It is also closely allied to A. Morelianus, d'Orbigny, but differs in the structure of its septa.

Locality and position.-Cretaceous beds at Komooks, Vancouver's Island; also in the lower division of the California Cretaceous at Cottonwood Creek, Shasta County, of that State.

\section{Genus NAUTILUS, Linnæus.}

\section{Nautilus Cavpbelli, Meek.}

Plate 6, figs. 2 and $2 a$.

Noutilus Campbelli, Meek (1861), Proceed. Acad. Nat. Sei. Philad., 318.

Shell large, subglobose, or somewhat oval, moderately conrex; periphery and sides rounded or slightly compressed; volutions increasing rather gradually in size, deeply embracing, and rounding into the umbilicus on each side; umbilicus very small, but not quite elosed; septa separated by spaces less than one-third the transverse diameter of the whorls at the point of measurement, arching slightly backward on the sides and periphery; aperture nearly circular, but deeply sinuous on the ventral side for the receptions of the inner whorls. Siphuncle and surface-markings unknown.

Length, or greatest diameter, 4.83 inches; breadth, or transverse diameter, 3.07 inches.

This fine Nautilus is much like $N$. Clementinus, a'Orbigny, as figured in his Paléont. Français, Terr. Crét., i, pl. 13 bis. It differs, however, in having a more rounded aperture and a more broadly-rounded periphery, the entire shell being less compressed.

It is perhaps more nearly allied to some varieties of the Indian form referred by Dr. Stoliczka to $N$. Bouchardianus, d'Orbigny ( $=N$. lacvigatus and $N$. spharicus, Forbes), some of which seem to be nearly as much compressed. None of these forms, however, show near so rounded an aperture or section of the volutions. Yet it is extremely difficult to distinguish these smooth Nautili of this type with such specimens as we usually get for study, and it is therefore possible that more extensive collections may show it to be necessary to unite the Vancouver shell with one of these foreign species.

It may be at once distinguished from Nautilus Dekayi (which has been identified by Dr. Shumard from Vancouver's Island) by its much more compressed form, narrowed aperture, and slightly open umbilicus, that of $N$. Dekayi being entirely closed at all ages by a solid shelly colnmella. Its whorls are also more compressed on the sides, and more concave in the region of the umbilicus, thus giving a very different form to its aperture and the section of its volutions.

The specitic name was given in honor of Mr. Archibald Campbell, the commissioner in charge of the Northwestern Boundary Survey.

I have given on the same plate (Fig. 3) for comparison, an outline showing a transverse section of one of the whorls of Nautilus Dekayi, taken from Dr. Morton's original specimen, in the collection of the Academy of Natural Sciences at Philadelphia.

Locality and position.-Komooks, Vancouver's Island; Cretaceous. 


\section{TERTIARY SPECIES?}

\section{Genus MACTRA, Linnæus.}

Mactra Gibbsana, Meek.

Plate 2, figs. $8,8 a$, and $8 b$.

Mactra Gibbsana, Meek (1861), Proceed. Acad. Nat. Sci. Philad., xiii, 315.

Shell transversely oval, or subtrigonal, moderately convex, rather thin; anterior side narrowly rounded; base forming a regular semi-elliptic curve; posterior side slightly truncated at the immediate extremity, abruptly rounded or subangular at its connection with the base below; dorsal outline sloping from the beaks in front and behind at an angle of about $120^{\circ}$; beaks central, rather elevated, but small, and not projecting much above the hinge-margin; surface marked only by moderately distinct lines of growth. Posterior muscular impression oval, well defined; pallial line distinct, and provided with a rather deep, horizontal sinus, which is about one-third longer than wide. inch.

Length, 2.04 inches; height, 1.50 inches; breadth or convexity, 1

Some eight or ten more or less perfect valves of this species were found near Port Discovery on the Straits of Fuca in a loose mass of rather hard, fine, gray sandstone, in which (when moistened and examined with a magnifier) numerous black grains may be seen. So far as I am able to determine, it belongs to an undescribed species, which I proposed to name in honor of Mr. George Gibbs, the geologist of the Boundary Survey. As the matrix in which it is embedded contains no other fossils, excepting fragments of an unknown Univalve, I have been unable to decide whether it is of Tertiary or Cretaceous age, though I incline to the opinion that it belongs to the former.

Mr. Conrad has described a similar Mactra under the name of $M$. albara from the Tertiary on the Columbia River (Am. Jour. Sci., vol. $\mathrm{v}, 2 \mathrm{~d}$ series, 432). The species before me, however, is proportionally longer and less gibbous. It also differs in being destitute of a distinct angle down the posterior umbonal slopes. It is likewise proportionally longer than any of the Cretaceous species described by Dr. Hayden and myself from Nebraska.

Locality and position.-Found loose on the Straits of Fuca; Cretaceous or Tertiary. 



\section{$\mathrm{PL} \triangle \mathrm{TE} 1$}

Fig. 1. Productus Litissinus; cast of interior of ventral valve, reduced to a little less than one-third diameter...........................

1 a. Outline profile of same.

1 b. Surface-striæ of same, magnified.

Fig. 2. Athyris subtilita ?, ventral view, reduced in same way $. . . \ldots \ldots \ldots . . . .$.

$2 a$. Dorsal view of same.

FiG. 3. SPIRIFER kEOKUK ?, ventral view, reduced in same way..............

3 a. Ventral view of a smaller individual, apparently of the same species, but proportionally shorter on the hinge-line; reduced in same way.

FIG, 4. An undetermined bivalve, presenting the form and external appearance of a Mactra or TANCredra; from New Castle Island, Nanaimo group, reduced in size as above.

4 a. Outline profile of same.

FrG. 5. Undetermined bivalve from same locality and position as last, reduced in same way.

5 a. Profile outline of same.

Fig. 6. Ixoceramus — Imperfect cast of a left valre, reduced in size as

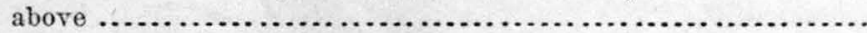

The dim shading beyond the broken posterior and basal margins represents the restored outline.

Note.-The figures on this and the following five plates were originally, in most cases, drawn of natural size, and arranged for quarto plates; but the whole were reduced for this;work to octavo size by photographs, from which the lithographer made his tracing, and then finished the figures from the original drawings. 


\section{CARBDNAF'ERDUS,}

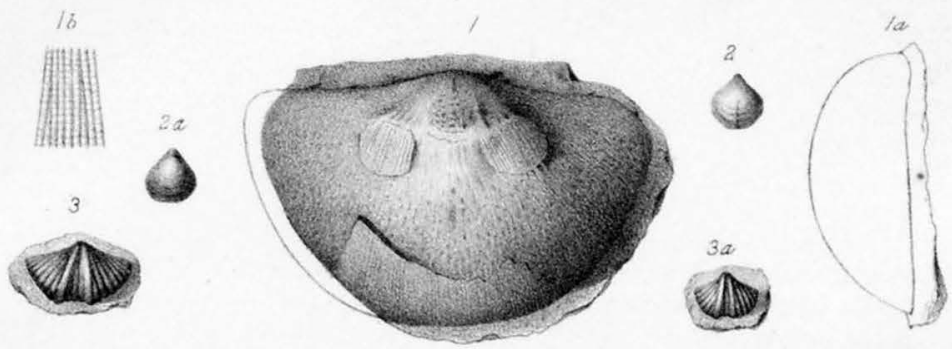

QPE'TACEDWS

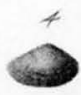

(Nanaime Beds.)
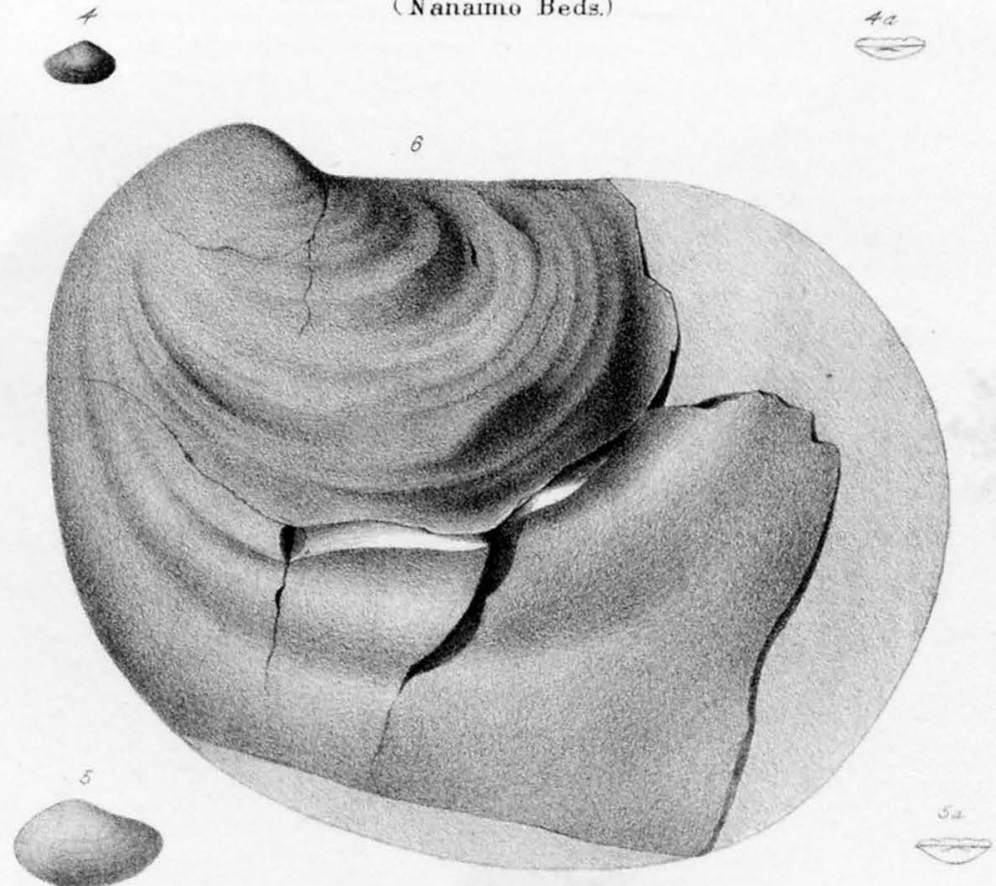




\section{PLATE 2 .}

Fig. 1. Phomadomya suberongata ; reduced to less than twc-thirds the natural

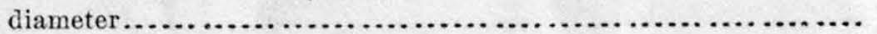

1 a. Dorsal view of same.

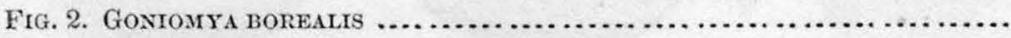

A left-side view, reduced in the same way.

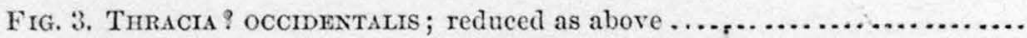

3 a. Dorsal view of same.

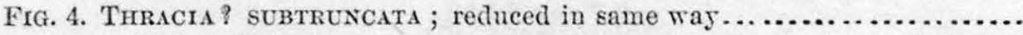

4 a. Dorsal view of same.

Fig. 5. Cyprimeria? tenuis; mould of exterior surface left in matrix, reduced

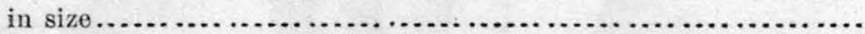

5 a. An internal east of a smaller specimen; reduced.

$5 \mathrm{~b}$. Profile of same.

Fig. 6. Arca equilateralis ; side view of an internal cast, showing muscular impressious and traces of radiating striæ, reduced in size as above..

6 a. Dorsal view of same species.

Frg. 7. Trigonia evansi; side view of the original imperfect specimen, reduced in size, and retaining portions of the shell .....................

7 a. Side view of a gutta-percha cast, taken from a nearly perfect monld or impression left in the rock; reduced in size.

$7 \mathrm{~b}$. A dorsal view of a cast from a mould left in the rock; reduced in size.

Fig. 8. Mactra gibbsana; reduced in size (age doubtful)

Page.

362

362

363

363

8 a. Portion of an internal east, showing the posterior muscular impression and the pallial line of same species; reduced as above.

8 b. Outline anterior view of same species. 

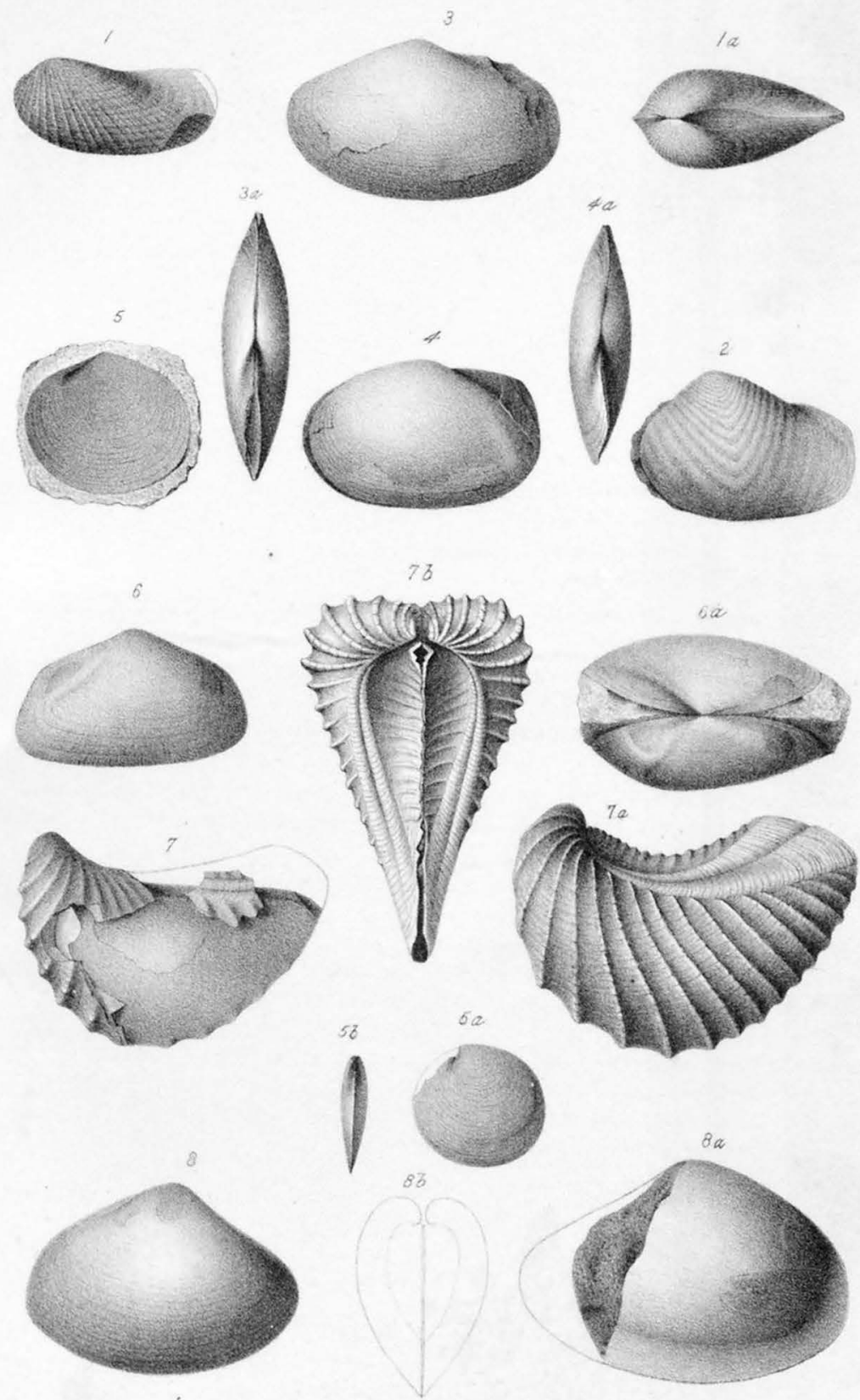

F. B. Yeek k W H Holres de?.

$\mathrm{Th}^{\text {en }}$ Sinclair \& Son lifh , Prila 




\section{PLATE 3.}

Fig. 1. INoceramus cripsir, var. subundatus; right valve, reduced to less than two-thirds the natural diameter............................. 1 a. Profile of same, in outline.

Fig. 2. Outline view of one of Morton's original specimens of Inoceramus Barabini, for comparison with figs. 1 and 3 ; reduced as above. 2 a. Profile of same.

Fig. 3. Inoceramus cripsir, var. stbundatus; left valve, reduced as above... $3 a$. Outline profile of same.

Fig. 4. Cardium (Protocardia) scrtulum; cross-lines showing natural size... 4 a. Right valve, enlarged.

Fig. 5. Grammatodon? vancouverensis; right valve, reduced as above...... 5 a. Profile view of same.

Fig. 6. Dentalium komooksensis; reduced as above.................... 368

Fig. 7. Heteroceras cooperi ; view of outer or dorsal side, reduced as above. 7 a. Ventral side of same. 
Bulletin. U.S.G.S.

CPETACEDTS

(Komooks Beds.)

PL III
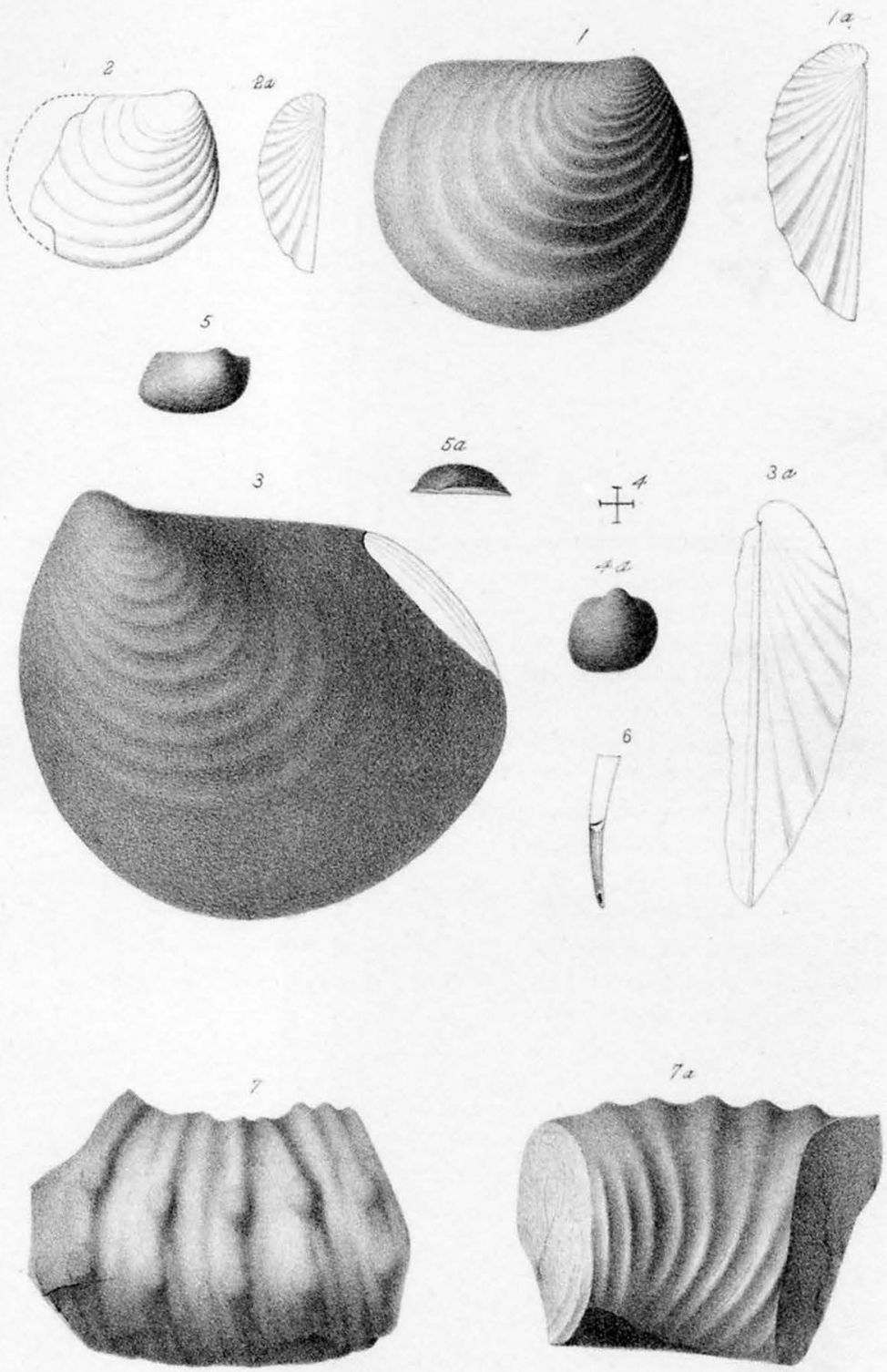




\section{PLATE 4.}

Fig. 1. Bacultres occidentalis; reduced to less than two-thirds the natural

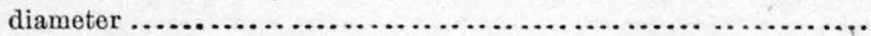

Page,

1 a. Section of same.

1 b. A septum of same, enlarged to about 2 diameters.

Fig. 2. Baculites chiccoensis; reduced as above

2 a. Section of same.

2 b. A septum of same, enlarged to about $2 \frac{1}{2}$ diameters.

2 c. First lateral lobe of same, on the opposite side (enlarged in same way), showing the differences in the details of this lobe on the two sides of the shell.

Fig. 3. Ammonttes newberryanus; side view reduced to about two-thirds the natural diameter .......................................

3 a. Peripheral view of same.

3 b. A septum of same, enlarged to about 3 diameters. 


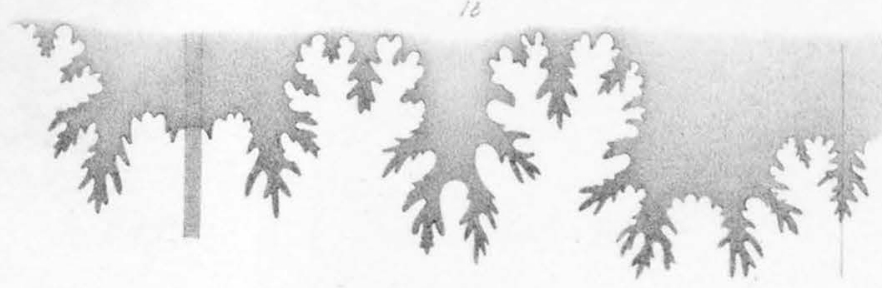

27
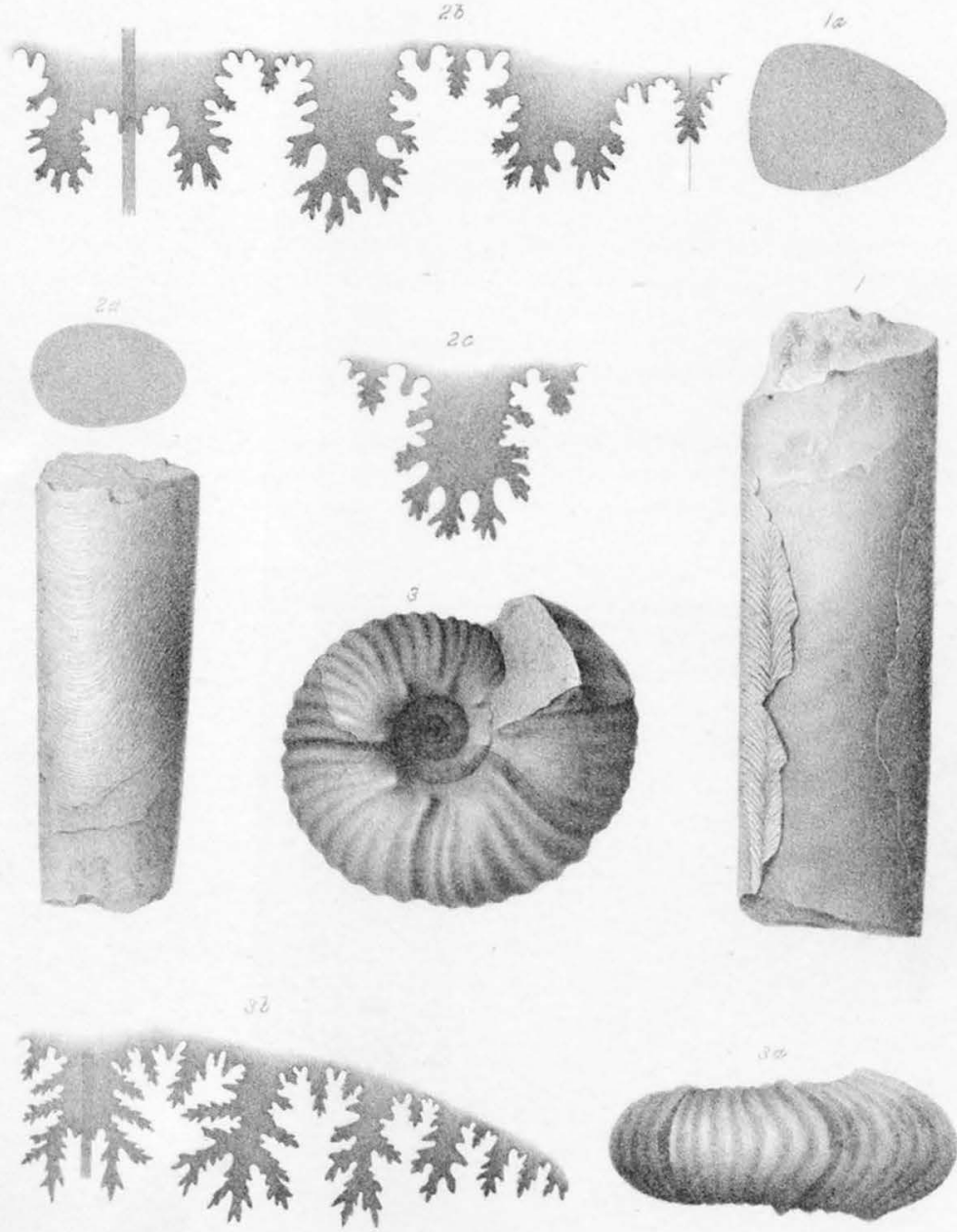



\section{PLATE 5 .}

Fig. 1. Phylloceras ramosus; side view, reduced to about two-thirds the

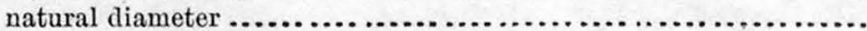

1 a. Outline profile view of same.

$1 b$. Part of a septum of same, showing the siphonal and first lateral lobes and the siphonal sinus, magnified.

Fig. 2. Ammonites complexus, var. suclaensis; side view of a medium-sized specimen from Komooks, reduced to about two-thirds the natural

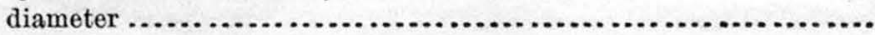

2 a. A part of a septum of same, enlarged.

$2 b$. A larger specimen from Sncia Island, being a worn internal cast, reduced as above.

2 c. Profile view of same. The siphonal lobes of the septa in this figure are traced in from the smaller specimen represented by fig. 2 of same plate. 
TPETACEDW S
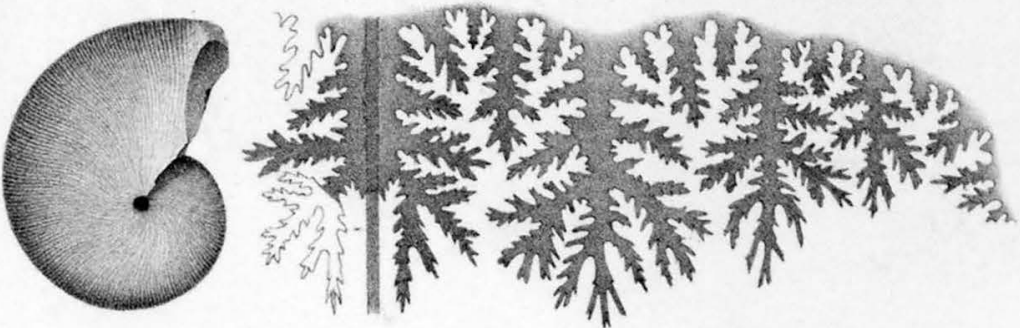

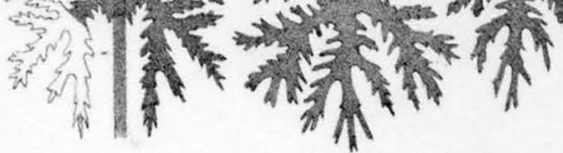
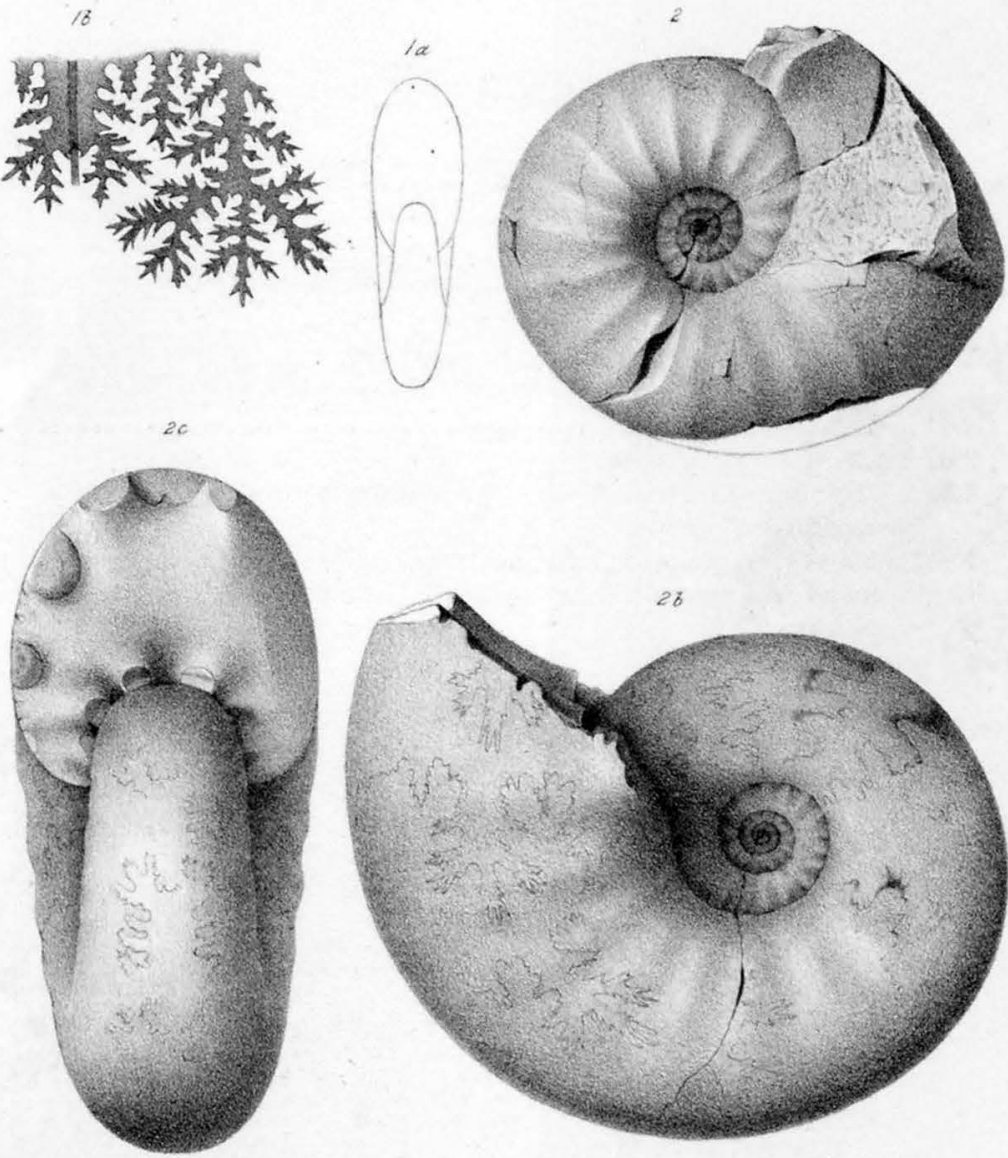

F. B. Meele det.

Th" Sinclair \& San liff Phila 



\section{PIATE 6.}

Fig. 1. Placenticeras? Vancouverensis; dorsal view, reduced to about two-

Page.

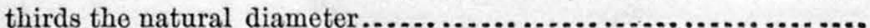

1 a. Lateral view of same.

$1 \mathrm{~b}$. Septum of same, enlarged to 3 diameters.

1 c. A section of one of the whorls.

Fig. 2. Nautilus Campbelir ; anterior view, reduced to about two-thirds the natural diameter

2 a. Lateral view of same.

Frg. 3. An outline section of one of the whorls of Nautilus Dekayi, taken from Dr. Morton's original specimen; reduced to about two-thirds the natural diameter. 
Bulletin, U.S.G.S.

CPETACEDTS

(Komooks Beds.)

PL.VI,

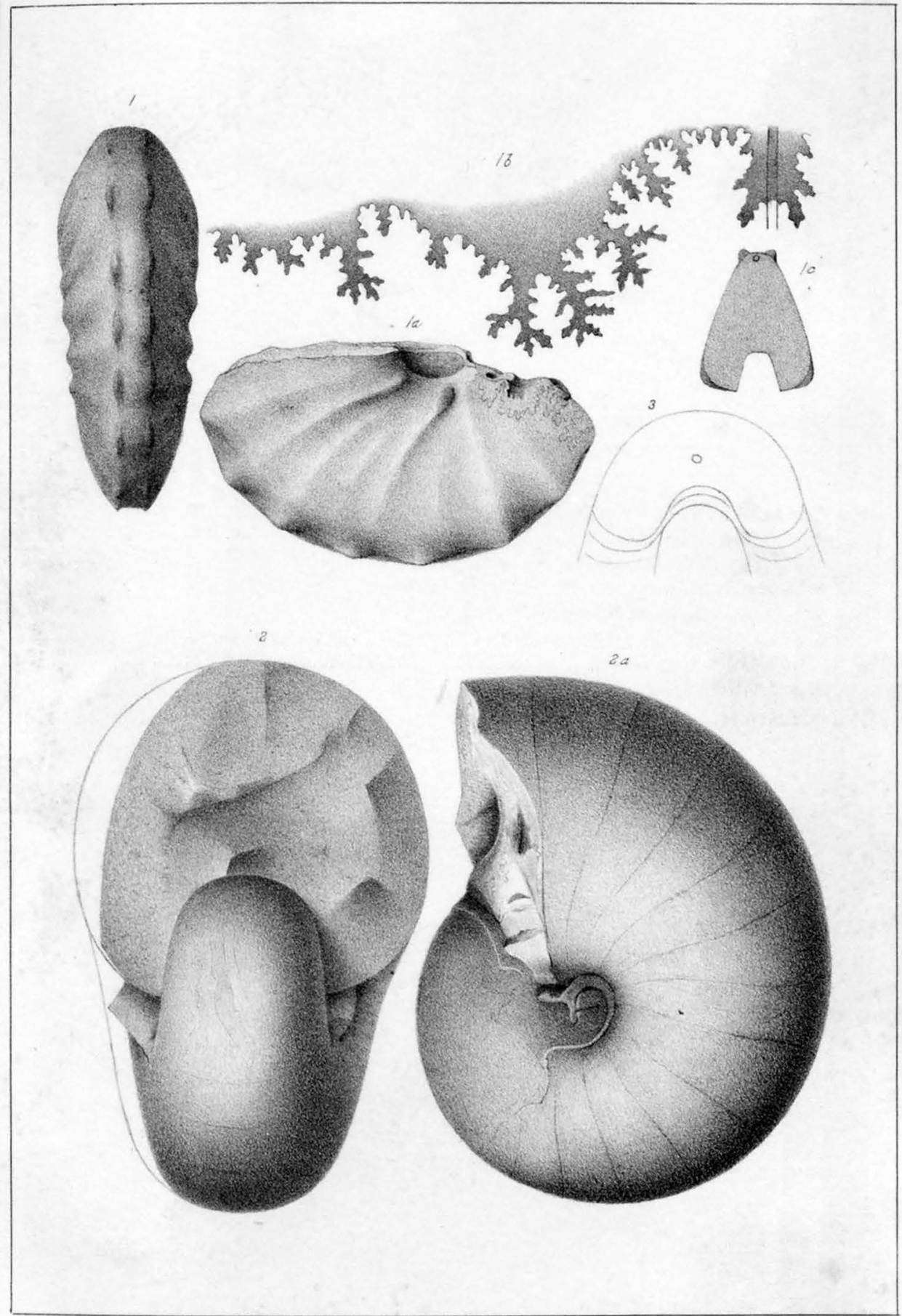

F. B Meelk del

The" Sinclair k Sen. lith, Prilla 